\title{
Selling the College Library's Services
}

Miss Stokes, second assistant librarian in charge of readers' service of the Pennsylvania State College Library, presented this paper at the Junior College Libraries Section of A.C.R.L., June 23, I942.

$\mathrm{I}^{\mathrm{T}}$

T WAS GRATIFYING to find in an article $I_{\text {in the March 5, 1942, Library Journal }}$ that a professor was advocating the same attitude on the part of college librarians as the librarians themselves have been cultivating for some time in many institutions of higher learning. The article, "The Instructor Looks to the Library and the Librarian" by Rob Roy MacGregor, of Southwestern College, pointed out that it is the librarian's job to sell the library to the faculty. Although the term selling is overworked and unpleasantly connotative, it is most appropriate for the sort of promotional activities the librarian carries on more or less informally. And a search of library literature reveals that many college and university librarians agree further with Professor MacGregor. They have concluded, as a result of all sorts of attempts to work directly with both students and faculty, that the faculty is the most effective link between the student and the library; so the best efforts of the library must be aimed at the faculty if the greatest number of students is to be reached.

Turning our best efforts upon the faculty is a subtle problem. In the first place, because many of us are not holders of the same degrees as the faculty with whom we deal, we cannot take the same respect for granted in the academic scalewe will have to work hard to deserve that respect and we will have to disregard sonie academic oversights. Then, we are not teachers by designation, and, to those who are, we must necessarily be in the same position as is the single woman who tries to tell her married friend how to bring up the baby. So we must take an attitude which, though certainly not humble, should be unfailingly tactful. We must be invariably ready to see the faculty point of view, yet maintain our own with consistency backed up by reasoning comprehensible to those outside of the library.

The business of selling the library to the faculty begins whenever the librarian meets his first instructor. If the instructor is preoccupied or taciturn, the librarian should hold off from any aggressive approach until a more suitable moment. Anyone familiar with academic prejudices knows how easily jealousies can be aroused by an incautious statement of plans for the advancement of a department or division of the college. Those men who feel their own work unappreciated are quick to try to thwart their colleagues' proposals by way of maintaining their own small prestige. But these same individuals, often quite susceptible to any sympathy or tact the librarian may exercise, can be lined up as substantial supporters of the library program if they are made to understand 
that the library will further their own interests.

For example, when the instructor begins to berate the library for the lack of books in his field, he should be requested to help in building up the material by submitting lists of necessary items. In the respite given him while the instructor assembles his lists, the librarian will have time to survey the field himself and will be ready with answers and arguments for the next encounter. If he has done a creditable job, the instructor, pleased to find someone with a knowledge and interest in his work, will respect the limitations the librarian will probably be forced to impose and will feel that his needs are being met with intelligence and considered effort.

\section{Knowing Faculty Members' Interests}

Knowing the interests of those faculty members who are really keeping up in their fields, who are publishing frequently and doing constructive teaching, will keep the librarian perpetually hopping among such widely different tasks as identifying Canadian pamphlets on the methods of freezing fish for commercial markets and searching for bibliographical notations of the many revisions of Erasmus' De Copia Verborum Ac Rerum. He must be somewhat like the school teacher who is employed to teach German, mathematics, and physical education, when all he is properly qualified to teach is French. Necessarily he must be continually studying ahead of his students so that they do not find him less informed than they are. The librarian will constantly have to refresh his memory of bibliographical sources as well as watch for new ones to be published. The recently printed Union List of Microfilms and the Directory of Micro- film Sources, for instance, opened up new possibilities to some of our faculty members and their research students who have been needing numerous interlibrary loans and photostats, besides having to make extended trips to other libraries during vacation periods. Recently we were able to borrow one film noted in the Union List at a total cost of eight cents for the round trip.

The developing uses of film must be closely watched if the research people are to receive maximum benefits from available resources. Although we have had two reading machines in our library system for some four or five years, we are still discovering people who do not know of them in spite of what we thought was adequate publicity at the time of their purchase. One professor happened to tell us this year how inconvenient he found using certain films because he had to turn his head to a very uncomfortable angle to read. Amazed, we showed him that the drum of the machine revolves to any position, making it possible for the reader to adjust his film any way he likes. This young professor is such an independent soul that he probably never bothered to have the machine fully demonstrated. The incident taught us that it is not enough to have the library assistants trained to show people how to use the reader; it is wise to have a sheet of instructions on display near the machine as well.

Occasionally a surprising gap becomes apparent in the background knowledge we take for granted in members of the faculty. The head of one of our professional courses had repeatedly blocked the purchase of a certain set of indexes for the branch library in his school. We thought 
him quite unreasonable because of this apparently arbitrary decision. However, the tact of the branch librarian eventually brought him to ask to see the index under discussion. He promptly admitted that he had some other index in mind and was not acquainted with this one, which he recognized as excellent, a most desirable addition to the branch library, and a wonderful tool for his own information as well.

\section{Faculty Handbook}

It is because we want to keep the faculty aware of our innovations and developments that we have printed every few years a handbook on the use of the library for faculty members. Some duplication of the student library handbook is inevitable, but in large part the approach and content will be different. We outline there the process of book selection and purchase so that the young instructor will not have to complain to us that his department head never gave him a chance to suggest any books to be added to the library. The method of having books placed on reserve is also described for the benefit of the newer faculty members who sometimes seem to expect reserve books to jump into their proper places in the reserve book room as soon as the titles cross their minds. The privilege of requesting books not in our collection as interlibrary loans or in film or photostat reproduction, the special accommodations available to faculty members in carrels or studies, are emphasized. The same detailed description of catalog filing practice which we use in the annual student handbook is included for the faculty. If we find many cases like that of the professor just mentioned, we may reconsider our decision that the indexes noted for the students were already so familiar to the faculty that they might be omitted from their handbook.

Each year we have a revised edition of the student handbook ready for the incoming freshmen. We regard it as a real link to instruction. To date it has been given out during Orientation Week while the freshmen are being conducted through the library. This year, with our speededup program, Orientation Week has had to be omitted. Freshmen are given a library problem, as they have been in other years, to be turned in to their English composition instructors; the handbooks are distributed at the same time. The problems are graded by the library staff and returned to the instructors who average the grade with the student's English marks. This is, however, only the beginning of our cooperation with the faculty in acquainting students with the library. A number of instructors come to us later in the year and arrange to have small classes given further instruction in the reference room or at the card catalog during a class period, at some time in their courses when the students are capable of realizing the importance of the library to their college work. Other instructors ask the reference department to suggest a few basic reference tools which they may describe to their students in class, especially before term papers with accompanying bibliographies are due. One such set of term papers from a class in English composition was checked by a reference librarian to see what the students were learning about the library from the professor's lectures. Information which seemed lacking in the majority of cases was stressed to the professor so that he 
could clear up those points later in going over the papers with his class.

\section{Reserve Book Room}

Since many undergraduates have their first independent library experience in the reserve book room, the administration of this service provides one of the most tangible ties to the teaching program. Either an inactive or an overburdened reserve book room can easily upset faculty and student library relationships. Some faculty members, not understanding the potentialities of a reserve collection, make inadequate use of it, creating the basis for unsatisfactory library service. We try to become acquainted with the needs of the individual problem professor to the point where we can suggest changes in his reserve requirements which will improve our service to his classes. In courses where long lists are used for collateral reading, the advisability of open-shelf collections is emphasized. Where one or two books are required reading for hundreds of students in a survey course, we have successfully used, to determine the number of copies necessary, the formula published in the Library Quarterly for July 1934 which was worked out by Margie M. Helm, librarian of Western Kentucky State Teachers College. An analysis of reading time required for assignments allows for flexibility in charge limits. Giving the early readers three- or seven-day charges and, in the last week or two before the assignment is due, limiting the late comers to two-hour or overnight use serves to reward the student who plans his work and keeps the books in constant use rather than overtaxed under last-minute pressure.

Although the freshman orientation program has been our most direct contact with the entire student body, we have tried many other ways of reaching smaller groups, especially with regard to recreational or background reading. Some ten years ago Willard P. Lewis, college librarian, began to issue a bulletin of book reviews and library news called The Headlight on Books at Penn State. It has become the policy of this publication to include in almost each one of its four annual numbers, under the heading, "The Inner Workings," a brief account of some phase of the work of the library. We hope that these articles help to clarify for our users certain of our practices and make them realize that we do not fit that popular concept of a librarian as a person who has lots of time to read during working hours. The book reviews in the Headlight are written by staff members, faculty, or students at the request of the editor, who tries to discover people interested in particular books or subjects and able to write readable reviews. Most of those asked to contribute accept with enthusiasm. Faculty wives also read the bulletin and seem pleased to have an opportunity to write for it themselves occasionally.

\section{Fraternity and Dormitory Libraries}

In $1933 \mathrm{Mr}$. Lewis compiled the Fraternity Five-Foot Shelf, a list of books recommended for purchase by fraternities interested in building up house libraries. The library offered, at the time of the distribution of the list, to order any books a house wished to buy, giving the fraternity the benefit of our rather generous discounts. This offer was accepted by a roughly estimated 20 per cent of the fraternities during those first years, but interest has waned since new fraternity 
members have come in and depression conditions have affected purchasing power.

We started to experiment in 1935 with dormitory libraries for men and women. The men's dormitories were all in one unit, so the collection of about fifty books selected for the men was set up in a room centrally located, which could be kept open by a student library assistant one hour each evening and locked up at other times. The women's dormitories had to be served by five different collections of twenty-five books apiece. Because we could not afford to have five student assistants to take care of them, they were simply placed in bookcases in accessible lobbies to be used any time the girls liked. Unfortunately, we found that we had to take heavy losses in books from the girls' buildings, while the boys' books stayed safely under our assistant's control. Gradually we won the active support of the hostesses of the girls' dormitories and placed the collections in their offices, though the hostesses were not expected to be responsible for the whereabouts of the books. The collections are selected with the students' tastes and recommendations in mind and are shifted by student assistants under the library's supervision so that fresh titles are frequently brought to each house. Although most of the books are recreational, two girls' dormitories last year requested encyclopedias. Rules for underclass women make it hard for them to get their library work completed before they must report to their buildings for the night. We had one set of the latest edition of the Britannica, lacking three volumes, and an old edition of the Americana, which were idle in our stacks. The representatives of the dormitories were asked to tea with the staff one afternoon, shown the available sets, and asked if they would be satisfactory as a trial measure. The girls seemed delighted at our immediate response and gladly agreed to see if real use would be made of such books. Circulation of the dormitory collections has never quite pleased us, though it has been increasing in the last two years. A recent study of the boys' titles shows that copies of the same book circulated three times from the central library to one time from the dormitory. The girls' titles circulated approximately the same number of times from both places. While these figures make the collections appear a luxury service to a specially privileged part of the student body, we are not yet ready to abandon the experiment, because the students so served are invariably enthusiastic when we talk with them about continuing the collections.

\section{Student Library Committee}

Two years ago the librarian requested the president of the student body to appoint a committee of students to represent the different classes and schools on the campus as a Student Library Committee. The committee numbers seven members, usually four men and three women, each member being replaced upon his graduation by someone from the sophomore class of the same school. The committee decides upon its chairman and secretary and meets with the librarian or his representative at irregular intervals, depending upon what matters are under discussion. One project which grew out of this committee's suggestions and efforts is the collection and organization of a file of past examinations given in college courses. Such exam files were maintained in many of the fraternity houses, but the file now housed in the reference room of the library is available to all the non- 
fraternity students as well. It drew great flocks of students, many of them not our regular users, to the reference room around examination periods and seemed to give them the feeling that the library is a friend, anxious to help them pass their courses creditably.

In the winter of $194 \mathrm{I}-42$ the student committee made a survey of student opinion of the library which had surprising results from the viewpoint of the librarians, though such results from random sampling can be considered only as an indication. A sampling of 5 per cent of the student body was interviewed by the committee members by telephone. The individual students contacted were those whose names appeared in the twentieth, fortieth, etc., positions in the student directory. One of five answers was possible under each of the four questions asked. The first question was: "How often do you use the college library?" Almost half of the students answered, "Occasionally," with just 3 per cent replying, "Never." Under the question, "To what extent does the library meet your personal needs?" 59.5 per cent replied that it was always adequate, while no one said, "Never." One of the most gratifying responses came under the third question, "To what degree do you think the library staff cooperates with the student body?" Ninety-one and nine tenths per cent said, "Always very helpful," while no one checked under either "Seldom" or "Never." Finally, "Do you have trouble finding the books you need?" was answered, "Never," by 46.6 per cent. Two and two tenths per cent said "Always," while the rest ranged between. Both the committee and the library had hoped that student dissatisfaction aired through the survey might give us an op- portunity to consider means of correcting the faults which caused annoyance. In a few instances the students volunteered unfavorable information not called for directly in the survey, but the complaints were the usual ones: not enough best sellers, all the good technical books in the branch libraries instead of at central. The students have as yet failed to point out to us any inefficiencies or faults in policy of which we were not quite conscious ourselves. But meeting their individual criticisms with honest explanations of the difficulties we are trying to overcome has resulted in increasingly pleasant relations between us.

So far only our attempts to sell the library to the faculty and students during our working hours have been mentioned. The extracurricular efforts we may make are almost equally important. We believe that a librarian who is just a bookworm or a retiring scholar has a limited value. The individual who is interested in many things besides books finds himself drawn quickly into various faculty and student activities. And, particularly when he is new in the college community, he is wise to be a bit undiscriminating about what he does-if he can bear to dance, play bridge, go to football games, student teas, or May Day festivals, his more weighty interests may go briefly on the shelf and he will drag himself out, even when he's had a hard day or it's a rainy night. After some months of these often wearisome efforts to indicate that he wants to take a part in the campus life, he can begin to refuse overtures here and there and let himself become identified with those groups most to his taste. But he will have learned, during his sampling period, much that will be useful in any administrative work he may do and will have 
made friends and supporters in corners of the campus often remote from the library.

The younger members of the library staff are encouraged to take courses in the college if they have such inclinations. An acquaintance with the prevailing methods of teaching is useful to the service departments of the library as well as to the catalogers and order librarians. It is easier for the librarians to understand the student viewpoint if they occasionally place themselves in the position of the student.

Many of the points that have been made are so familiar that it must seem unnecessary to repeat them. Yet these few experiences of ours-only the more unusual ones have been selected, of course-may perhaps serve as reminders of some plan that was evolving but had to be put off until circumstances were more propitious. We often say that the library is the heart of the college, but if that heart is allowed to run down or become hardened by lack of constant intelligent care for its continued health, we may look about us someday to find that a restaurant in the village or the office of the college daily paper has taken the place we should claim in the campus affections. We will do well to cultivate the attitude of the gracious hostess who keeps her guests comfortable and amused but never lets herself become overtired and sour with the great strain upon her own energies. Or perhaps we should emulate the good salesman who believes so thoroughly in his product that his enthusiasm never flags while there remains a single person to whom he may introduce it.

In her article in the March 1942 issue of the Journal of Higher Education,
"Overcoming Library Illiteracy," Mrs. Lorene Garloch Byers, reference librarian of the University of Pittsburgh Library, concludes quite logically, "If the college students of today can be trained in the use of the library, the professors of the future will use the library with greater ease and frequency and education will ultimately reach a higher level, with the library functioning as the center of the instructional program." But work directly with today's students, desirable though it undoubtedly is and certainly deserving of our repeated efforts, does not approach the continuity of what we can accomplish with the faculty. Our girls' dormitories may have this year students who are interested in encyclopedias for their house collection. When these students have been graduated, the group living in the dormitory may be so indifferent to those encyclopedias that we are guilty of cluttering the hostesses' offices unnecessarily by leaving them there unused. Our boys' dormitories have been converted this fall into housing for girls, because of war conditions, so their collection of books chosen for male tastes has had to be replaced with titles appealing to girls. The examination file so carefully built up in our reference department by the Student Library Committee is already in a decline after its one year of great usefulness, because the elimination of exam week from the speeded-up program has caused the finals in most courses to be changed to fit into a class period. The Student Library Committee members have been so busy these last shortened semesters that the usual quota of their meetings has had to be cut to the very minimum, lessening the committee's usefulness considerably.

On the faculty side, however, the 
things we have done are maintaining their importance: the professors who helped us build up the collections in poetry and anthropology are keeping their students constantly using those books. Although Freshman Orientation Week may be lost for some years, those instructors who have always carried library instruction further into their class periods are continuing to ask the library for help and cooperation in their programs and are reaching large groups of students who may pay little attention to our handbooks and problems. The research men whom we have helped with interlibrary loans are becoming better scholars with greater depths of knowledge to bring to the students working under them. The professor who learned about a basic index is certainly calling that index to the attention of his staff members, many of whom were probably as unacquainted as he was with the immense body of material that the index could make easily available to them. The contacts we have made with students at teas and receptions may result in one to four years of pleasant relations, but the faculty members we have come to know well during years of sociability may be valuable supporters of the library's next budget increase campaign which is for the purpose of improving services to the student body as well as to the faculty.

Mrs. Byers' statement, then, should certainly influence our long-time planning, but Theodore Norton, librarian of Lafayette College Library, in School and Society in 1936, under the title "The College Library and College Teaching," has given us a sound recipe for immediate dividends from our efforts: "Guarantee to the undergraduate good teachers and the good teachers will see that the undergraduates make effective use of the book collection."

\section{College and University Library News, 194I-42}

(Continued from page II4)

were those of Peyton Hurt of Williams ${ }^{236}$ and Sabra W. Vought, one time of Tennessee and later of Pennsylvania State. ${ }^{233}$

Charles H. Brown delivered the A.L.A. presidential gavel to Keyes D. Metcalf. ${ }^{237}$ Fanny E. Lowes was given the degree of Doctor of Literature at Washington and Jefferson. $^{230}$ Several university librarians, representative of those active, retired, and

${ }^{236}$ L.J. $67: 323$.
${ }_{237}$ A.L.A. Bull. $36: \mathrm{P}-37-38$. deceased, were honored in print. The work of Herbert S. Hirshberg was recounted in the Bulletin of Bibliography ; ${ }^{238}$ a number of the Library Quarterly was dedicated to Louis Round Wilson ; ${ }^{239}$ and College and Research Libraries carried brief articles on Theodore Wesley Koch ${ }^{240}$ and Justin Winsor. ${ }^{241}$

\footnotetext{
${ }^{238} \mathrm{Bull}$. of Bib. 17:105-07.

239 L. $Q$. $12: 339-773$.

${ }^{240}$ C.E.R.L. $3: 67-70$
}

241 Ibid. 3:64-66. 